\title{
Competitive Strategies of Islamic Banks: A Case of Pakistan
}

\author{
Hamid Hussain $^{1 *} \quad$ Sadia Khatoon ${ }^{2} \quad$ Zahid Sarwar $^{1}$ \\ 1. School of Business Administration, Dongbei University of Finance and Economics, China \\ 2. School of Business administration, Jilin University, China
}

\begin{abstract}
The main aim of this study is to examine the competitive strategies of Islamic banks in Pakistan that they should adapt to compete in the banking industry. To achieve the aim, the authors conduct a study which is based on a theoretical framework. We examine the current situation of Islamic banking by investigating the current external environment using PEST (Political, Economic, Social and Technological) analysis, the industrial environment using Porter's Five Forces Model and internal environment using resource and competency analysis based on SWOT frame (Strengths, Weaknesses, Opportunities and Threats). The authors find that Islamic banks should employ differentiation strategy aimed at achieving a competitive advantage by offering better services and products. For achieving competitive position Islamic banks should adopt marketing tactics for attaining large market share, and conduct training workshops to deliver knowledge about Islamic banking to employees and also create awareness about the importance of interest-free banking in general public. This research paper is the first to examine the competitive strategies of Islamic banks in Pakistan the results of this study are valuable to Islamic Banks in Pakistan and the industry as it exposes the gaps in their strategy, which is addressed in time will help deter competition. They are also capable of gauging the success of the banks in employing specific competitive strategies.
\end{abstract}

Keywords: Pakistan. Islamic banks, Competitive strategies, Differentiation, SWOT, PEST.

DOI: $10.7176 / \mathrm{JPCR} / 46-02$

Publication date: November $30^{\text {th }} 2019$

\section{Introduction}

Islamic banking is now a well-known term and has become one of the most significant and significant industry worldwide. It is known for his concept of without interest or interest-free banking and operates in different Muslim and non-Muslims counties. (Noman, 2002)

The sector of the Islamic Bank in Pakistan has been growing at the fastest pace since its re-launch in 2001. Additionally, Starting from almost scratch, the IB sector now represents $15 \%$ market share in the banking industry with 21 different financial institutions including five full-time Islamic banks offering financial services and offering different banking products. The progress of the IBs has shown outstanding growth in their assets, deposits, reserves and expanding business volume in the country. Since 1990 the service business in the country and in the global environment particularly the sector of banking are growing this creates a competitive situation in the country. The entry of IBs in the country's banking industry affects the system controlled by adjusting the forces of demand and supply for money. Islamic banks ensure more stable business sector as compared to traditional banks (Khan, 1998).

The IBs sector is facing various challenges for the reason that of the strong reaction from conventional banks because they were deeply rooted and famous with the public to fulfil their financial needs and also enjoyed monopoly since 1947- 2001. The growing's of new IPs and even rise in the number of traditional banks in Pakistan creates a competitive atmosphere in the industry of banking in the country. The sector of banking of Pakistan has witnessed a critical change because of the role of the private banks having $80 \%$ assets of the banking. In Pakistan today, the banks are facing the pressure of running their businesses due to the intense competition between the banks in their industry.

Banking has traditionally operated in a relatively stable atmosphere for years. However, nowadays the industry is facing dramatically aggressive competition in a new deregulated environment. IBs in Pakistan realise that stiff competition within the industry necessitates the design of competitive strategies to guarantee their performance. Successful strategies lead to superior performance and sustainable competitive advantage (M. E. Porter, 2008). A business can command a competitive advantage rely on the sustainability of the competitive advantages that they control. The business environment in the country has drastically changed because of the opening of many IBs and therefore rising in the rivalry in the industry of banking in Pakistan.

This study looks at the competitive strategies being pursued by newly growing IBs in Pakistan to achieve a competitive position in the banking industry of Pakistan. For any new business to succeed in the long term ethically issues must be handled carefully, so we will also examine the ethical perspective along with cultural values as well, and also we are not considering Islamic banking "in parameters of religion", but we are finding it newly growing banking sector. (Dulo, 2006), state that bank has to consider how to come into the market and then how to form and protect its competitive position. Guided by these facts, there is a need, to formulate a study 
on the banking industry in Pakistan, specifically to understand the strategies for IBs of Pakistan. The researcher intends to bridge this gap by carrying out a study that will examine the competitive policies adopted by Islamic Banks in Pakistan to gain a competitive advantage over their competitors; this study will answer the following research questions:

1. What are the strengths, weaknesses, opportunities and threats of the Islamic banking sector?

2. What will competitive strategies be suitable for Islamic banks to gain a competitive position in the banking industry?

The focus of the current study is to explore competitive strategies of newly growing Islamic banking sector in Pakistan. This research is conduct to know how Islamic banks can sustain in the competitive banking industry in Pakistan by adopting opportunities and threats and what kind of strategies they should adopt to gain a competitive advantage in the dual banking system in Pakistan.

\subsection{Method}

This study is based on a theoretical framework, theories, existing research and strategies models to get the appropriate and final result of the investigation. PEST (Political, Economic, Social and Technological) frame and Porter's five forces model are used to analyse the external environment of Islamic banks in Pakistan. Recoursebased and capabilities views are used to analyse the internal environment of Islamic banks and SWOT (Strengths, Weaknesses, Opportunities and Threats) analysis.

\section{Theoretical background \& Literature Review 2.1 Theoretical background}

The word "strategy" has always been linked in any discussion of the issue management within an organisation and been prominent as of its significance. (Pitts \& Lei, 2006), explain that to assure it that an organisation applies its strengths and special competencies in such a way that it is achieving a competitive advantage over its competitors in a distinct environment. (Chandler, 1990), he defined that the assurance of the long-term goals and objectives of a business and the adoption of causes of action and the allocation of resources for carrying out these goals".

Competitive strategy is for searching a favourable position when competing in an industry where the competition occurs. The sustainability of this position desires advantage that the business set up barriers that make it difficult to imitation, as these obstacles corrode regular emulation, the company needs to continue to receive investor improve the advantage (M. E. Porter, 2008).

The competitive advantage that enables the company to function more efficiently or higher in a manner otherwise the quality manner of firms that compete with, which results in benefits that accrue to that company (Adjei, 2012).

Generic strategies bring three different ways thoroughly into a competitive advantage, combining a choice about the type of competitive advantage desired with the strategic objective of the scope of that competitive advantage to be gained. The purpose of cost leadership and differentiation strategies is at a competitive advantage in a broad range of industry segments. On the other hand focusing on strategies target cost focus of differentiation in a narrow segment (R. Hall, 1993).

The Cost leadership strategy is a combined set of activities taken to produce goods or services with single features that are sold to clients at the low cost compared to rivals or at a low price to achieve superior profitability. (Dess \& Davis, 1984), find that the total low-cost cluster has confirmed that the return on the average asset is the highest. According to (Powers \& Hahn, 2004) that the cost leadership strategy provides statistically significant performance benefits.

In the cost leadership, a bank sets out to become a low-cost service provider in the industry, and thus develops a range of banking services and products deliver in many industry segments. The sources of cost advantage are diverse in the banking industry considering the structure of the industry. Regarding (Hankinson, 2001), low-cost producers typically sell a no-frills, standard product and place considerable emphasis on absolute cost advantage from total sources.

The theory behind differentiation strategy, according to (M. Porter, 1980), need to determine the features that differentiate him from the competition, that is, it must be a truly unique company of its kind in something or perceived to be that way if you were expecting a higher price. Contrasting this attitude with the cost leadership, there are more than successful differentiation strategies in the industry if there are numerous of the attributes of value on a large scale by consumers.

In spite of the strategies mentioned above, low cost and differentiation in achieving its objectives all over the industry aim to focus on well-defined target market very well; this is taken into mind when carving practical strategies - the overall strategy to focus lies on a competitive selection a narrow range in the business. The focuser chooses a group or a segment in the sector or industry and tailors its strategy to serve them to the exclusion. There are two variants of focus strategy, called cost focus and differentiation focus. 
In the cost focus strategy an organisation seeks a cost advantage in its target segment; on the other hand, differentiation focus seeks differentiation in its target segment. Both of them rest the difference between a focused target and segment in the industry. The target segments or group must either be a buyer with mutual desires or else in the delivery and production system that serves the target segment must be different from those of other industrial sectors. Focus cost of exploiting differences in the cost behaviour in some industries, while differentiation focus spirited the particular desires of buyers in some sectors (Wright, 1987).

It is must to any bank if that want to focus select a group or segment in the industry where it is operating and tailor its strategy to serving them to the omission of others. By improving its strategy, the target segments, the focuser seeks to achieve a general competitive advantage (Pagan 1985). There are two types of focus strategies in banking. Cost focus Bank is the kind that tries to cost advantage in target customer segment, while the bank seeks to focus differentiation bank find in the customer segment. Both types of strategies rest on differences between focuser targets segments and different segments in the industry (Czinkota \& Kotabe, 1990).

Banks that focus on the cost will attempt to exploit the differences in the behaviour of the cost in some of the targeted segment of customers while the focus of differentiation deeds the superior desires of the buyers in a particular segment (Barney, 1991).

The idea inherent the concept of generic strategies is that competitive advantage is at the core of every strategy. Accomplish competitive advantage needs the bank to choose the type of competitive advantage.

According to (Fleisher \& Bensoussan, 2003), It is a managerial tool used in strategic management and marketing in an evaluation of the weaknesses and strengths of the potential competitors in the market. It provides both defensive and offensive strategic context through which to recognise threats and opportunities in the business. Competitor profiling combines all related sources of competitor analysis in a single frame to support the efficiency and effectiveness of the strategy formulation and implementation, monitoring and adjustment. Given that the interpretation of the competitor is an essential element of the company's strategy, it is claimed that most companies do not conduct this kind of analysis regularly enough. As a substitute, many enterprises run on what is called "Impressions informal, guesswork, intuition gained through tidbits of information about competitors every manager has continually received." As a result, the old-style environmental scanning puts many companies vulnerable to the risk of dangerous competitive blind spots because of the absence of a robust competitor analysis (Fleisher \& Bensoussan, 2003).

\subsection{Literature Review}

Organisations need an effective competitive strategy to operate successfully in the market where there is established and potential competition. Choosing a competitive strategy which will deliver competitive advantage is an inexact process (Capon, 2008). He also says that the achievement of competitive advantage and hence superior profits are central to the strategy of any organisation. Also, the achievement of competitive advantage is likely to result if a company is clear about its competitive strategy.

According to (Ekeowa, 2015), the application of competitive strategies in any firm improves communication that is necessary to carry out the managerial functions and for linking the organisation with its outside environment. Competitive strategies, therefore, must provide a communication link that makes the activities and responsibilities surrounding management or managers possible.

(D. J. Hall \& Saias, 1980), Investigated sixty-four US companies and the results of the research revealed that the following companies had a differentiation strategy superior performance matched to those companies that were not following it. It is important that analysts note that there is more than one way in which a company can make use of differentiation. Differentiation can be accomplished through high-quality, customer service and differentiated products etc. The main question is whether the customers of the company to understand or recognise the difference among others or not.

(Chan-Olmsted \& Jamison, 2001), conducted a research study on competitive strategies applied by banks in China from 1978 to 1998 . The writer states that the sector witnessed, important players "entering and leaving different legal standards were met, structure and the passion of competition became different, and making trade/differentiation became the principal significant element of rivalry in that period.(Di Patti \& Gobbi, 2001), Conducted a study on the effect of competition in commercial banks in Italy. Fifteen commercial banks in Rome were sampled. From his study, they found that competition leads to higher growth rates and greater access to credit for new businesses and other SMEs. However, it was found that competition has adverse effects including less new business creation, expansion and employment, economic growth and slow output less mature companies.(Carletti \& Hartmann, 2003), conducted a survey of 231 microfinance institutions in London on the impact of competition on financial stability. During the search, investigators found that the degree of competition in the financial sector can import access for businesses and households to financial services and external funding, in turn, affects the whole growth of global economy.

According to (Dirisu, Iyiola, \& Ibidunni, 2013), the expansion of business strategy has to do with customers matching "requirements (needs, wants, desires, preferences and buying habits) with the capabilities of the 
organization, centered on the skills and resources existing to the business organization or a company, leading to the question of core competency. They posit that the concept is something the organisation does, at least, like other organisations, or preferably better than any other organisation in the market thus competitive strategy defines the distinctive tactic which the business plans to practice to achieve success in every of its strategic business areas. It provides a firm with an advantage over their rivals in customer acquisition and defence against competitive forces that give the customers what they perceive as a higher value in services or goods at a low price. Superior service worth paying more for, or the best value representing an attractive combination of price, features, service, quality, and other aspects that buyers find attractive (Ogutu \& Samuel, 2012).

An experimental study by (Powers \& Hahn, 2004) in the USA, indicated that competitive methods used by banks in the financial service industry adapt to generic strategy forms and banks following a cost leadership strategy. They are noticing a statistically significant higher performance compared to banks that are stuck-in-themiddle the study point out that for some banks that pursued a broad differentiation, customer service differentiation, or focus strategy reported above-average earnings which were reported less frequently. They thus suggested that superior performance is harder to realise for banks following one of these strategic directions than it is for banks following a cost leadership.

This is contrary to findings in Kenya by (Muro, Magutu, \& Getembe, 2013), which showed that Equity Bank, one of the fastest growing banks adopted an array of product differentiation strategies to raise profitability. Some of these strategies to achieve the differentiation include involvement of clienteles in product development through focused group discussions (FGDs), aligning products with customer desires and the environment in which they are being offered to ensure customers can identify themselves with the same.

(Obeidat, 2016), described the significance of trained human capital or resource for long term successful banking. He explained the different aspects of social capital development in the banking industry. He noticed that skill level of a significant segment of the human capital in Indian banks was not up to the standard, and they supposed that banks pursuing key performance enhancements had no option but to stun these problems speedily.

(Bordia, Kronenberg, \& Neely, 2005), researched on - Improve productivity to make the most of branch popularity study has created a framework for understanding the drivers of performance. As well as staff roles and time-spend, it has identified four other drivers: network size and structure, sales process effectiveness, performance measurement and management and process efficiency.

(Kohli, 2001), have discussed numerous features such as manual to the computerised bank, stage of computerisation in the nationalised banks, new Indian private sector banks and foreign banks. He discovered that advancements in telecommunications and information technology had revolutionised the financial and banking on the net is fast catching on. As e-commerce gets transformed into $\mathrm{m}$-commerce with the increasing use of technologies, banking business is in for a significant overhaul.

\section{Environmental Analysis of Islamic Banking in Pakistan \\ 3.1.1 Political Conditions}

There is a political instability since the independence of Pakistan, and it is struggling for the democratic government for a long time. Because of the political trend, the civilian and military governments have failed to implement and formulate the long term policies. From their interest, every government changes the policies with a different slogan. State bank of Pakistan (SBP) was under the control of the Ministry of Finance there was an influenced from the ruling groups in the country, also an enormous pressure on the government from different religious groups during the making of policies which were sensitive in the matter of religion aspect.

But now there is a positive aspect that the state bank of Pakistan (SBP) is an independent organisation in making its decisions. Therefore now in Pakistan, the banking industry is enjoying the long term policies. The SBP has played a crucial role in the banking reforms and also providing the guidelines for the newly IB sector. Now in Pakistan, the environment becomes stable, and the religious groups are also favoured for the IB sector in Pakistan. So, near the future, there is no chance in changes in the significant policies. Therefore, the IBs can make their strategies under the guidelines of SBP. The SBP is also promoting Islamic banking, and it has stopped giving the licenses to the traditional banks. So, like this legislation is a favour for the IB sector.

\subsubsection{Economic Conditions}

The economic condition of the state is a significant effect on the success of the many firms and industry. Before the strategic planning of any organisation, all the organisations are examining the economic conditions of the country. Pakistan economy was the model for developing countries, but unfortunately, the war with India and there was a shortage of inconsistency in policies, and many other factors affect negatively on the country economy. Now the economy is stabilising results of the new reforms which are which were implemented a few years ago. These reforms including tax reforms, reformation of the banking sector, trade liberalisation and energy sector deregulation etc. as compared to past the GDP growth rate is increasing, and the per capita income is also increased. FDI is also growing year to year. As the country economy is showing stability and consistency slowly from the last few years, which is a good sign for the banking industry of the country as well as the Islamic 
banking sector.

\subsubsection{Socio-Culture Conditions}

Extended study of local culture and social arrangement is also one of the main factors that consider in successful strategy development. Different cultures have various kinds of consumer behaviour. religion as "A group of basic principles, ideas, needs and behaviours accepted by a member of society from family and different social institutions." (Kotler, 2009).

Pakistan geographical location is very significant because of its diversified culture. Almost $95 \%$ of the population's religion is Islam, and it has a durable and long-lasting effect on lifestyle and attitudes of that particular area. Besides, this is the 6th largest populous country in the world. So IBs is favourable as consumers want to deal financing in an Islamic way. Banks are using consumer's religious belief to flourish Islamic banking around the country.

\subsubsection{Technological Conditions}

Technology plays as a positive catalyst to change the work pattern and goal of the firms. A rapid change in technology replaces the old version. It's essential for marketers to know the new technology to serve customers efficiently (Kotler, 2002).

Technology has come up with a new look for business and services as well. It has also brought a radical change in the banking industry. Banks are providing numerous types of facilities to their clients with the blessings of technology. Although the IT sector has brought innovative changes in the technology world, Pakistan infrastructure is not up to the mark in the technological industry. The banking sector has introduced a lot of innovative services with the help of technology. Islamic banks are also on its way, but it is growing slowly compared to the potential needs of Islamic banking in the country.

\subsection{Industrial Competitiveness Analysis}

Competitive strategy means how the company is related to its environment. The environment can be huge including social, economic and Political but the primary setting of the organisation is the industry in which an organisation is operating. For example, for Islamic banks, the banking industry is the critical environment. Forces external of the industry is of vital importance in determining the overall efficiency of the industry. These forces affect all the businesses in them, but the method of dealing with these forces vary from firm to firm.

The state of competition for a company relies on the fives competing forces. The total strength of these forces defines the progress and success of the company (M. E. Porter, 2008).

The strength of these forces varies from company to company. It is intense in companies like paper and food where competition is intense, and it is deficient in companies like oil field equipment and car manufacturing.

\subsection{Porter Five Forces Model}

\subsection{Intensity of Rivalry among Existing Competitors}

The recent scenario of IB is highly competitive, and it's growing over time. Competition is extreme among Islamic banking and traditional banking in metropolitan cities. While there is much demand for Islamic banking in rural areas, banks are not paying attention to deliver service in rural areas. So there is a potential market for Islamic banks in rural areas of Pakistan.

In Pakistan, both traditional and Islamic banks are doing their business. Many of the domestic and foreign traditional banks are launching new Islamic banking units, and it creates intense competition. Another critical issue is only $12 \%$ of the total industry are captured by Islamic banking and rest is belongs to conventional banking.

According to (M. E. Porter, 2008) the nature of visions, goals and strategies are used to judge competition by different companies within the industry. Although IB has its vision and purpose, overall plans are almost similar to Islamic and conventional banking.

\subsubsection{Threat of New Entrant}

The flexible policies and the deregulation of the banking industry by SBP for Islamic banking, it makes it easy to enter for new entrants in the IB sector. Now in Pakistan, six Islamic banks are operating, and the SBP is still willing to give more licenses for new Islamic banks to promote Islamic banking. Traditional banks are also entering in the IB sector; they are opening Islamic banking sections in their branches and want to give a choice for their customer.

The SBP raised the requirements of capital for entry in the banking industry. Therefore, it would be a problematic entrance in the industry. The giant banks in the industry already maintained the economy of scale, and it will be tough for new entrants to compete in the industry with other banks.

\subsubsection{Bargaining Power of Buyers,}

In Pakistan, a big part of the population is living in the rural areas, as compared to rural areas in urban areas clients are much concentrated, so there are various choices and options for the buyers in the urban areas among 
different banks. In Pakistan out of the overall population, only $15-19 \%$ peoples are using different financial services. Only 4-7 \% of peoples are using Islamic banking services. The institutions and customers are both concerned with the more profit and attracted to higher on investment and deposit.

The mainstream of the peoples have low income, and it is quite expensive to opening account in the banks, so there are interested in those banks which services charges are low then as other banks. Nowadays in Pakistan customers have more information and options about financial services, there is competition in banking and banks are spending many funds on marketing and advertising of their products. In conclusion, as related to rural areas the bargaining power of customers is high in urban areas and as compared to individuals institutions have more energy.

\subsubsection{Bargaining Power of Suppliers,}

In the IB sector, suppliers have significant power. The critical strength of suppliers of IBs is the Shirah board or shariah scholars. Shortage of good Shirah scholar results they demand higher charges for their services because without design and permission of products from Shirah scholars the IB transaction is not possible. Similarly, there is a shortage of trained staff and professional, and they are also demanding higher charges of their services, so the Islamic banks' professionals and trained staff have many opportunities in the career, because of increasing competition day by day.

In conclusion, in the Islamic banking sector, the power of supplier is high, and the shariah board holds the critical power of the banks because without the approval of shariah board the bank can't make a transaction.

\subsubsection{Threat of Substitute}

In Pakistan, there are several different financial and mutual funds companies are providing the services. The SBP is also encouraging opens the small microfinance institutions to low income and poor peoples in the country. But as compared to Islamic banks the growth of small microfinance banks is low. In conclusion, the threats of substitutes are not high in the banking industry of Pakistan for IBs.

\subsection{Resources-Based and Capability Analysis}

Every organisation is a unique set of resources and capabilities that make available the base for its strategy and the primary source of their income. In the highly competitive landscape in the 21 st century, a firm is a set of capabilities that manage to evolve dynamically in chase of higher returns than average (Barrney, 1991).

The primary principle of the resources based view is that support for a competitive advantage of a business lies primarily in the utilisation of the bundle of useful resources at the organisations' disposal (Lamb, 1984). To transform a short-term competitive advantage into a maintainable competitive advantage have needed these resources are diversified in nature and not fully mobile. Efficiently, this translates into useful resources that are not either perfectly substitutable or imitable without a huge effort. If these circumstances hold, the firm's role of resources may comfort the company sustaining above-average returns. The sector of IBS and its assets are increasing, but the marketplace was found to be low on employees who have been qualified in Shariah compliant banking system, lack of staff and new human resource in IB sector.

The major elements for achieving a prominent position, long term success and handling customer relationships in the financial industry is, investing in sophisticated strategic human resources process (Ryals \& Knox, 2001). However, in a situation of newly growing Islamic banking, with limited knowledge about how to conduct transactions from the Islamic aspect and about the technicalities of Shariah rulings, employees faced difficulties in dealing with customers about the features of Islamic financial services and products (Kahf, 2004).

In the IB sector, a human resource has significant power. The main strength of suppliers of Islamic banks is the Shirah board or shariah scholars. Shortage of good Shirah scholar results they demand higher amounts for their professional services because without design and permission of products from Shirah scholars the Islamic banks' transaction is impossible. Similarly, there is a shortage of trained staff and professional, and they are also demanding higher wages for their services.

The Product Structuring and Research is the conception point of innovation of products and services as per Shariah guidance. Different products and services have been developed to meet formerly addressed the financial needs of the customers. Besides developing new products, the Product Structuring and Research function also investigate to refine, modify and redefine current commercial products. Providing personalised Shariahcompliant financial solutions to Corporate, the Shariah Supervisory Board which includes planning the meetings of the Shariah board, preparing agenda items to be presented in the conference, rolling out the decisions taken in the Shariah board meeting across the bank as well as insure decent application of the rulings.

\section{Strategies of Islamic Banks in Pakistan \\ 4.1 SWOT Analyses}

\subsubsection{Strengths of Islamic Banks}

In Pakistan, IBs are working in parallel with traditional banks offer a choice to the customers. Before Islamic banks, many of the people were not doing business with conventional banks (interest based banks) because of 
their strong believes against interest-based banking. These people were generally from the low class and middle class. Now they have the opportunity to take a loan from Islamic banks without interest and invest it into different businesses (Husain, 2006), IBs are now available in more than 85 cities in Pakistan. But on the side traditional banks, which cover almost the whole of Pakistan, including small and large cities. In the money market, the objective is to meet the Liquidity desires whenever they rise. The market promotes those banks which need money to borrow the excess sum of the other banks. Islamic money market performs the same actions to meet short-term liquidity needs, but instead of interest, Islamic banks make it easier to divide the amount of the surplus on the base of profit and loss. Traditional banks and take benefit of the Islamic capital market through Islamic branches. However, Islamic banks will be complete only to deal with the Islamic capital market, and cannot take benefit of the traditional capital markets.

There is not a lot of product differentiation in Islamic banks. However, the products are different from traditional banks. But as is the case, now the conventional banks are likewise opening Islamic branches, this is the reason for differentiating between products decidedly less.

\subsubsection{Weakness of Islamic Banks}

In Pakistan, SBP has the sole authority in issuing the license to the banks. Now, the capital requirement of getting the license from the state bank of Pakistan has reached $\$ 100$ million. State bank has also given the suspension order of providing of new bank license. State bank of Pakistan has stopped providing licenses to commercial banks, but are giving license to Islamic banks.

The distribution costs of Islamic banks products, as well as documentary and legal costs, are much high as the traditional banks. The reason that's why IBs are focusing on only a single transaction. There is the unavailability of a universal frame to do all the transactions.

There is also unavailable of standardization of Islamic banking tools. Approval of each transaction by Shariah Council is also the biggest obstacle to the proper development of Islamic banking. Shariah board is the new board; it makes Islamic banking unique from conventional banking. There is also a shortage of good scholars of Shariah and not out a full different view on the same product by various scholars; it is why the time required for the proper structuring of the new product and transactions is extended and also take much time for new innovative products. The weakness of Islamic Bank which differentiates Islamic banking Practices are not widely known as a commercial bank, growth in size with lack of sufficiently well-trained staff, a one-stop variety of Product at par with traditional banks and Lack of ongoing training for staff - both general and Islamic banking.

\subsubsection{Opportunities of Islamic Banks}

The government has provided a structure about legislative on which helped to reduce complications and time delays in recovering delinquent loans. (Khan, 1998), Although the risk involved in making Islamic banking transactions is much higher, this structure will considerably cut down the chances.

The Islamic banking sector has more opportunity for business in Pakistan because the government has a competitive tax framework. The Government promotes Islamic banking Industry, which will helpful for IBS to gain more market share in the coming years.

The increasing rate of GDP and per capita income growth reflects the economy of the country will improve. Foreign direct investment is a little better in the country, and one of the main attractions sectors for foreigner investors is the financial business. A growing economy and increased consumption capacity can act as a fueling demand for Islamic loans and investments of consumers and businesses.

Although the rate of literacy in Pakistan is low but is growing day by day, many professionals in the market have bright ideas, but don't have sufficient investment to start a new business or not resources for higher education or study abroad. IBs can provide more credit and introduce new transactions for these young, educated people really can enjoy extra market share and also help in reducing unemployment in Pakistan.

Microfinance is the main business of IBS and is the major industry in terms of Pakistan's potential customers. IBs have great potential to make a significant investment in this industry and can gain profit.

One-third of Pakistan's populace is living in rural areas, and the majority of them are engaged in agricultural activities or agriculture business in any way. There is a lack of significant financial institutions to provide services to the agriculture sector. Thus, Islamic banks can take benefit from this sector, because of low competition (Maden \& Kabasakal, 2014).

IB sector has started his business in the 21 st century, which is the era of IT. They have many opportunities in e-banking and online banking. Information technology and communication sector are growing in Pakistan, IBs can benefit from this by facilitating their clients through various forms of IT and telecommunications.

Pakistan is a populous Muslim country, and $97 \%$ of the peoples are Muslim. Most of them do not do business with traditional banks because of their strong religious belief against interest-based financial services. Total of six full-fledged IBs are operating in a country, and they have a large pool of clients interested in the decision of Islamic banking. 


\subsubsection{Threats for Islamic Banks}

There is a relation between political uncertainty and per capita GDP growth, political uncertainty harms economic growth, and both in the long-term policies are not effectively implemented. (Alesina, Özler, Roubini, \& Swagel, 1996), There has been a political uncertainty in the country, as a government, as it changes again and again. Each new Govt. introduces new policies and previous policies are often cut off. Moreover, this is a severe threat to the new growing an IB sector, as they face the different challenges in the implementation of long-term policies in the country.

It has been common practice in Pakistan that some people from influential groups take loans from banks and not repay their loans. Pakistani entering the restraint group category of uncertainty. People believe in rumours without justification and confirmation. A significant number of people in Pakistan have misconception or doubts about these banks, whether these banks are Islamic are really Islamic or just using the label of Islam and do the same as the traditional banks. Additionally, This is a potent threat for newly growing IB sector. Inadequate physical infrastructure exists in Pakistan. So IBs have to face problems in managing their business to remote locations, which on the other end can be a definite market point for IBs.

It is an incontestable fact that the current business environment, more and more vigorous and companies are always faced with stiff competition in an industry from current competitors and new entrants. The banking industry is no exception to this competition. Therefore, to make sure the constancy and success, companies must develop the ability and potential to manage threats and feat emerging opportunities quickly (Chiteli, 2013). It assumed that this requires the formulation of a competitive strategy that refers to the positioning of the firm to get the most out of the features that distinguish it from its competitors. To access the industry's position to compete in a competitive environment (M. Porter, 1980).

Concerning the Johnson and (Thompson \& Strickland, 1992) they modified Porter's strategies in three approaches, the first one is cost leadership, differentiation and the focus or niche strategy. They called them market facing general plans copied from Bowman and (Ilinitch, D'Aveni, \& Lewin, 1996), by principles that companies achieve competitive advantage by offering their clients with what they want or need, better or more effective than competitors. Customers will choose which offer to acquire in their perception of worth for money.

\subsection{Strategies Formulation; Differentiation strategy}

A central plank in achieving competitive advantage is an appreciation of a firm's internal capacities and external environment. For an organisation to gain a competitive advantage, it has to provide its customers with what they need or want better or more effectively than competitors. Customers will choose which offer to accept their perception of value-for-money.

As a service-oriented organisation, the image is a dominant factor in the efforts of a bank to differentiate it from competitors. In general, the way the products and services are available to customers helps create the image of the particular institution in the notices of customers. This image is imitated in feelings and perception about product or service offered to customers.

During the study, we found that there are several prospects for the growth of IB in Pakistan and the environment is favourable for the sector. There is much potential for already running IBs and new investors in this segment as well. Although there is political uncertainty in the country, the free position of SBP is providing shelter to this sector against political instability. SBP has provided the IB sector with sufficient legislation and policies, as to assist this sector and increase its efficiency. Although the economic condition has shown healthy growth in the previous years the rise in inflation rate (due to multiple factors) can cause problems for investors. The socio-cultural factors of Pakistan are in favour of IBs, but it requires to be appropriately addressed and carefully. Pakistan is an Islamic democratic country, so there are many opportunities and much space available for Islamic financial institution's, including Islamic banks. There is also one problem that the public is not very educated and the rate of literacy is low; that's why many people think that IBs are just using the label of the religion. Otherwise, they are the same as conventional banks

Competition is high in the banking industry of Pakistan. IBs are new in the industry. There are many traditional banks are operating already in the industry. But the growth of IBs is good, but still, they are far behind from the conventional banks concerning market share. There are a lot of obstacles in the development of the Islamic banking, like separate shariah boards of each bank and shortage of educated human resource, lack of services, products, high prices or services charges from customer, problems in distribution channels, absence of awareness in the public about Islamic banking, information technology etc.

Islam forbids interest. In other words, Islam does not permit the money to rise solely by charging interest on credits, which means that the money grows by giving a credit today and hoping to get more of that in future due to interest. Islam encourages trade, but not the importance.

As we mentioned above, Pakistan is a Muslim state; about $95-97 \%$ of peoples are Muslim. Most of the people were not doing business with traditional banks because of their strong believes against interest-based banking. These people were generally from the low class and middle class. In the banking industry, much 
potential is available for Islamic banks, so we are suggesting that the IBs should implement the porter's differentiation strategy to take a competitive position in the industry. Since IBs are alternative of traditional banking, IBs should be differentiating itself it in term of products, services, pricing, distribution, promotion etc. Islamic banks also should offer new services and products to their customer. A good design differentiation strategy is suggested for IBS which will help IBs to achieve a competitive position in the industry.

\subsection{Strategies Implementation}

Furthermore, to achieve business goals and objectives, a business needs not only good strategic plan, but also a well-executed application of the plan .It is believed that implementation is as important, or even more critical, than strategy. The fact is that both are critical to success. Firms can achieve competitive advantage over implementation if completed successfully (Kotler, 2002). The competitive strategies of IBs should be implemented base on the following differentiation strategies

\subsubsection{Product Differentiation}

Product differentiation is an essential attractive strategy to pursue. Innovation is the basis of success in any business, and this holds in the banking industry as well. The changing nature of banking itself requires expansion of the products that can facilitate customers in conducting their transactions with a bank as well as the services and products which generates higher value to the customer. It's straightforward for clients to switch banking operations due to highly competitive rivals, but if a bank keeps on updating its services and products, it can retain customers and increase their trust and loyalty.

Under the product differentiation, the customer must also be able to link a specific image with a specific. Since customers using services and products to fulfil their needs and wants, IBs have to recognise the nature of these demands to appreciate the kind benefits customers expect to receive. Among the different kinds of benefits that people expect to get when purchasing goods and services includes good money value, novelty, availability, and ease of use.

Since IBs are a substitute for traditional banking, IBs needed to innovative and differentiated itself in terms of products and services. Only through innovation in services and products can Islamic banks sustain their competitive advantage as other conventional or foreign banks that offer similar Shariah compliance facilities.

So far IBs are using two products, i.e. leasing and cost plus for doing their businesses. They should introduce more innovative services and products for customers. We know that they have many products but are reluctant to use those products. Innovation is the key which will differentiate them from traditional banking.

The IBs should introduce new products which could be done through more research on Islamic laws and principles related to finance and consumer behaviour. Innovation can be of different natures like product innovation, service innovation and process innovation (Davenport, 2006). Islamic banks must have separate research departments, and the Shariah board should assist this department. IBs should have more advanced products which should be according to Shariah. They should go beyond the traditional type of banking, which only the upper class of the populace can take part. They should bring more innovation using technology like IT and telecom and introduce a varied variety of services and products, to capture the maximum pool of clients.

\subsubsection{Service Differentiation}

Well-Conceived service differentiation is significant for services oriented businesses to differentiate itself from competitors. Service experiences may create good or bad feelings and perceptions among customers. If they have positive attitudes regarding bank services as satisfied customers, they may repeat their transactions with the bank. On another side, dissatisfied and unhappy clients may think to shift to other banks.

IBs should differentiate itself obviously from other competitors in the industry. They should offer various kinds of service and transactions like inquiry funds transfer, financing payments, utility bills payments and mobile phones per paid reload. They should advance their services by mixing of old facilities and new technology to meet customers' expectancy for superior performance for coming as service excellence has a strong, good effect on the customer. It is suggested that IBs should try to build awareness about the importance of interest-free banking among bank customers by attractive advertising tactics and also through religious scholar's to attract a more significant number of customers. Islamic bank should actively introduce new and different innovation according to the guidelines of Shariah. Islamic banks must rise worth of service to fulfil their client hopes for long term profits. They are also required to implement an efficient and effective mechanism to measure the quality of services

\subsubsection{Location Differentiation}

Location differentiation is an attractive strategy. If pursued efficiently, it can bring stability and growth. This strategy is very critical if the bank wants to keep up its peculiar position. Moreover, This can be done by extending its branch network to countryside areas where people are need of customised banking solutions. The increased accessibility will provide the bank to achieve out to a higher pool of potential customers.

Mostly IBs and traditional banks are situated in the city areas. We described earlier that there is much more potential available for IBs in the rural areas and small towns. IBS have far fewer branches as to traditional banks. 
Islamic banks should increase their branches, and they should pay special consideration to small cities and urban areas, as there lies much more potential in those areas.

During the study, we found that $1 / 3$ of the population is living in remote areas and there is a shortage of financial services for them. People of rural areas are comparatively more religious than those of urban areas. Female population has also been ignored to target by other financial institutions. We suggested that IBs should widen their activities to those parts and go to capture and involve the female segment of the population as it constitutes a big set of consumers. This strategy is "Diversification" regarding the Ansoff Matrix. Diversification means new products, new services in a new market place.

\subsubsection{Pricing Differentiation}

Price is one of the significant factors affecting buyer choice and needs to be cohesive with the strategy you picked. Pricing differentiation is also another technique that can be used to increase a bank's overall competitiveness. The key to success is to establish well-planned strategies and policies to ensure continuous monitoring of operating costs, prices and profits. A significant portion of the pricing strategy is determining how service or product is priced. It is proved in various earlier investigations that many clients are not using religion as the key feature when they are starting a connection with IBs.

As we have explained in the earlier chapters that mainstream of people in Pakistan belong to the middle class and are very price sensitive. And as the competition is getting intense day by day with more banks entering in the Islamic banking sector and the bargaining power of people is also higher, so people have now more choices and they choose the particular service on the base of the price. Price of Islamic banks products/services should be lower than the traditional banks or at least the same as their competitors or traditional banks.

\subsubsection{Information Technology}

The vast technological developments in computer science and telecommunications, beside the developments in management science, have run to significant dependence on information, computerised activities and computerised systems in particular. Banking is one of the biggest customers of these technologies. Furthermore, to enhance ATM based financial services - financial globalisation and information explosion banks rely heavily on computer production capabilities, money transfer, automated banks...etc., and doubled the need to advance banking sector and improve its services. The Islamic bank's IT infrastructure should be frequently reviewed and updated to confirm that they are using the most efficient technologies on the market. The banks should also improve its data backup systems to avoid the incidents of server downtime, and disowning of service to customers as a result of communication link going offline. Hence, implementing the application of IT must be pre and parallel to achieving other differentiation strategies.

\subsubsection{Development of Human Resource}

(Armstrong, 1982) emphasises that "human resource is the primary factor for success in any organisation. (Lee \& Miller, 1999), has also noted that one of the fundamental resources needed to implement a strategy of the organisation is its human capital. Therefore, a workforce dedicated and brilliant can assist as a limited resource value, not imitable that can support the company implement a strategy for proper positioning.

As we discussed before in SWOT analysis reveals that the weaknesses of IBs are a shortage of an "experienced" and trained workforce and shariah scholars as its competitor conventional banks. Due to the firm root of traditional banks in the country, the newly growing IB sector is facing different challenges in the industry. In the banking industry the rivalry is too high, already there are several traditional banks are in the industry. But the growth of IB sector is good but still far behind from conventional banks in term of market share. There are many difficulties for IBs like shortage of shariah scholars for each bank, trained and educated human resource; well-planned human resource strategies etc. Therefore the IBs must pay consideration about the human resource strategies; they should conduct different training programs to their staff, should attend seminars, different learning programs, arranges programs in universities about the knowledge of IB and also should offer attractive packages for talented graduates from prestigious school to join IB sector. The banks also should address their talent gap by enrolling in capacity building programs. They should are provide training to their staff in leadership and management development platforms offered by different Islamic shariah schools. Additionally, This may result in a strong and long term HR strategy will develop, and fruitful for the achieving competitive edge against the traditional banks.

Understanding the shortage of trained staff in the literature, Islamic banks human resource divisions and the related agencies should grow a long term strategy in the area of human resources for the recruitment, development and training rather quick fix options (Ali \& Farrukh, 2013).

\section{The conclusion}

Including Pakistan, there is a swift transition has come in the financial services in the world. New banking called Islamic banking (IB) has been introduced in different Muslim and non-Muslim countries including Pakistan. In our thesis, we studied the current situation of Islamic banking (IB) sector in Pakistan and examined the competitive strategies for Islamic banks with the help of PEST analysis, SWOT and Porter Five Forces. 
During the study, we found that there is a high rivalry in the banking industry. Already there are several conventional banks which have deep roots in the economy. Now the IB sector is new in the market but the growth is good but they still far behind in term of market share from conventional banks. There are a lot of obstacles in the development of the IB in Pakistan like separate 'Shariah' boards of each bank and shortage of professional human resource, well design strategies etc.

After the study, we suggest that the IBs in Pakistan should adopt porter's differentiation strategy in a broad sense as a primary competitive strategy. It aims to achieve a competitive position to offer various kinds of services and products to their target customers. IBs should introduce more advanced functions and products for their customers. We know that in Pakistan, there is a vast potential for IBs because the population is Muslim majority. So, the IBs should make investments in the branding of their services and products; upgrade latest and update their information technology system and manage training for their staff, create awareness and importance of interest-free banking. In aspect of religion, should make sure about the prices of services be lower than conventional banks or at least the same with competitors etc. expend their branches to the rural areas to gain more market share. Branding confirms client royalty, a responsible and trained personnel empowers the banks to grow sustained and strong customer satisfaction, and improved information technology system allows the workforce to be more efficient. Information technology rebellion in the internet and mobile has developed a fundamental driver of rivalry in the bank industry by eliminating some entry barriers and allowing development of new products. These things will make it easy to IBs to achieve a competitive position in the banking industry of the country.

\section{References}

Adjei, H. (2012). Distribution Strategies in the Telecommunication Industry [A Case Study of Vodafone].

Alesina, A., Özler, S., Roubini, N., \& Swagel, P. (1996). Political instability and economic growth. Journal of Economic growth, 1(2), 189-211.

Ali, S., \& Farrukh, F. (2013). Islamic banking: Is the confidence level of being an Islamic banking employee better than conventional banking employee? An exploratory study regarding Islamic banking. Journal of Business Studies Quarterly, 4(3), 27.

Armstrong, J. S. (1982). The value of formal planning for strategic decisions: Review of empirical research. Strategic management journal, 3(3), 197-211.

Barney, J. (1991). Firm resources and sustained competitive advantage. Journal of management, 17(1), 99-120.

Barrney, J. (1991). Firm resources and sustainable competitive advantage. Journal of management, 17(1), 99120.

Bordia, R., Kronenberg, E., \& Neely, D. (2005). Innovation's ORGANA. Booz Allen Hamilton.

Capon, C. (2008). Understanding strategic management: Pearson Education.

Carletti, E., \& Hartmann, P. (2003). Competition and stability: What's unique about banking. Monetary history, exchanges rates and financial markets: Essays in honour of Charles Goodhart, 2, 202-229.

Chan-Olmsted, S., \& Jamison, M. (2001). Rivalry through alliances:: Competitive strategy in the global telecommunications market. European Management Journal, 19(3), 317-331.

Chandler, A. D. (1990). Strategy and structure: Chapters in the history of the industrial enterprise (Vol. 120): MIT Press.

Chiteli, N. (2013). Agent banking operations as a competitive strategy of commercial banks in Kisumu city. International journal of business and Social Science, 4(13).

Czinkota, M., \& Kotabe, M. (1990). Product development of the Japanese way. Journal of Business Strategy, 11(6), 31-36.

Davenport, T. H. (2006). Competing on analytics. Harvard business review, 84(1), 98.

Dess, G. G., \& Davis, P. S. (1984). Porter's (1980) generic strategies as determinants of strategic group membership and organisational performance. Academy of Management Journal, 27(3), 467-488.

Di Patti, E. B., \& Gobbi, G. (2001). The changing structure of local credit markets: are small businesses particular? Journal of Banking \& Finance, 25(12), 2209-2237.

Dirisu, J. I., Iyiola, O., \& Ibidunni, O. (2013). Product differentiation: A tool of competitive advantage and optimal organisational performance (A study of Unilever Nigeria PLC). European Scientific Journal, ESJ, 9(34).

Dulo, G. (2006). The sources of competitive advantage and the performance of firms in the Kenya sugar industry. Unpublished MBA Project. School of the Business University of Nairobi.

Ekeowa, L. N. (2015). Team Work Approach to the Management of Change in Selected Manufacturing Organizations in Nigeria.

Fleisher, C. S., \& Bensoussan, B. E. (2003). Strategic and competitive analysis: methods and techniques for analysing business competition: Prentice Hall Upper Saddle River, NJ.

Hall, D. J., \& Saias, M. A. (1980). The strategy follows structure! Strategic management journal, 1(2), 149-163. 
Hall, R. (1993). A framework linking intangible resources and capabilities to sustainable competitive advantage. Strategic management journal, 14(8), 607-618.

Hankinson, G. (2001). Location branding: A study of the branding practices of 12 English cities. Journal of Brand Management, 9(2), 127-142.

Husain, I. (2006). Economic Policy Reforms in Pakistan 1999-2006. Paper presented at the A paper presented at the Conference on Economic Policy Reforms in Asia held at Stanford University, Palo Alto on June 1.

Ilinitch, A. Y., D'Aveni, R. A., \& Lewin, A. Y. (1996). New organisational forms and strategies for managing in hypercompetitive environments. Organization Science, 7(3), 211-220.

Kahf, M. (2004). Success Factors of Islamic Banks. Paper presented at the Brunei Symposium on Islamic Banking and Finance.

Khan, M. Z. (1998). Transforming banking in Pakistan. The study commissioned by ADB for RETA, 5770.

Kohli, S. (2001). Indian Banking Industry: Emerging Challenges. IBA Bulletin, 23(3), 48-54.

Kotler, P. (2002). Marketing management (Millenium edition): Pearson Custom.

Kotler, P. (2009). Marketing management: A South Asian perspective: Pearson Education India.

Lamb, R. (1984). Competitive strategic management: Prentice Hall.

Lee, J., \& Miller, D. (1999). People matter: Commitment to employees, strategy and performance in Korean firms. Strategic management journal, 20(6), 579-593.

Maden, C., \& Kabasakal, H. (2014). The simultaneous effects of fit with organisations, jobs and supervisors on primary employee outcomes in Turkish banks: does organisational support matter? The International Journal of Human Resource Management, 25(3), 341-366.

Muro, M. B., Magutu, P. O., \& Getembe, K. N. (2013). The strategic benefits and challenges in the use of customer relationship management systems among commercial banks in Kenya. European Scientific Journal, ESJ, 9(13).

Noman, A. M. (2002). Imperatives of financial innovation for Islamic banks. International Journal of Islamic Financial Services, 4(3).

Obeidat, Z. M. (2016). Human Capital Investment And Training In Islamic Banking Industry In Jordan Jordan Islamic Bank for Finance and Investment. European Scientific Journal, ESJ, 12(10), 90.

Ogutu, M., \& Samuel, C. M. (2012). Strategies adopted by multinational corporations to cope with competition in Kenya. DBA Africa Management Review, 2(3), 69-82.

Pitts, R. A., \& Lei, D. (2006). Strategic management: Building and sustaining competitive advantage: SouthWestern Pub.

Porter, M. (1980). Competitive Strategy-Techniques for Analysis Industries and Competitors, New York: Free Press.

Porter, M. E. (2008). Competitive strategy: Techniques for analysing industries and competitors: Simon and Schuster.

Powers, T. L., \& Hahn, W. (2004). Critical competitive methods, generic strategies, and firm performance. International Journal of Bank Marketing, 22(1), 43-64.

Ryals, L., \& Knox, S. (2001). Cross-functional issues in the implementation of relationship marketing through customer relationship management. European Management Journal, 19(5), 534-542.

Thompson, A. A., \& Strickland, A. (1992). Strategic management: concepts and cases, Irwin: Inc.

Wright, P. (1987). A refinement of Porter's strategies. Strategic management journal, 8(1), 93-101. 